University of New Hampshire

University of New Hampshire Scholars' Repository

Earth Systems Research Center

Institute for the Study of Earth, Oceans, and

Space (EOS)

$12-23-2016$

\title{
Winter soil respiration in a humid temperate forest: The roles of moisture, temperature, and snowpack
}

\author{
Alexandra R. Contosta \\ University of New Hampshire, Durham, Alix.Contosta@unh.edu \\ Elizabeth A. Burakowski \\ University of New Hampshire, Durham, elizabeth.burakowski@unh.edu \\ Ruth K. Varner \\ University of New Hampshire, Durham, ruth.varner@unh.edu \\ Serita D. Frey \\ University of New Hampshire, Durham, serita.frey@unh.edu
}

Follow this and additional works at: https://scholars.unh.edu/ersc

Comments

This is an article published by AGU in Journal of Geophysical Research: Biogeosciences in 2016, available online:

https://dx.doi.org/10.1002/2016JG003450

\section{Recommended Citation}

Contosta, A. R., E. A. Burakowski, R. K. Varner, and S. D. Frey (2016), Winter soil respiration in a humid temperate forest: The roles of moisture, temperature, and snowpack, J. Geophys. Res. Biogeosci., 121, 3072-3088, https://dx.doi.org/10.1002/2016JG003450

This Article is brought to you for free and open access by the Institute for the Study of Earth, Oceans, and Space (EOS) at University of New Hampshire Scholars' Repository. It has been accepted for inclusion in Earth Systems Research Center by an authorized administrator of University of New Hampshire Scholars' Repository. For more information, please contact Scholarly.Communication@unh.edu. 


\section{Journal of Geophysical Research: Biogeosciences}

\section{RESEARCH ARTICLE \\ 10.1002/2016JG003450 \\ Winter soil respiration in a humid temperate forest: The roles of moisture, temperature, and snowpack}

Key Points:

- Variable controls on $\mathrm{CO}_{2}$ flux within a single soil-to-snow profile

- Soil moisture had a negative control on $\mathrm{CO}_{2}$ flux from soil; soil temperature had a positive control on $\mathrm{CO}_{2}$ flux from the snowpack

- Changes in soil moisture and temperature were driven by shifts in air temperature and snow depth

Supporting Information:

- Table S1

Correspondence to:

A. R. Contosta,

alix.contosta@unh.edu

Citation:

Contosta, A. R., E. A. Burakowski, R. K. Varner, and S. D. Frey (2016), Winter soil respiration in a humid temperate forest: The roles of moisture, temperature, and snowpack, J. Geophys. Res. Biogeosci., 121, 3072-3088, doi:10.1002/2016JG003450.

Received 11 APR 2016 Accepted 22 NOV 2016

Accepted article online 9 DEC 2016

Published online 23 DEC 2016

O2016. American Geophysical Union All Rights Reserved.

\author{
Alexandra R. Contosta' ${ }^{1}$, Elizabeth A. Burakowski ${ }^{1,2}$ iD, Ruth K. Varner ${ }^{1}$ (D), and Serita D. Frey ${ }^{3}$ iD \\ ${ }^{1}$ Earth Systems Research Center, Institute for the Study of Earth, Oceans, and Space, University of New Hampshire, Durham, \\ New Hampshire, USA, ${ }^{2}$ Climate and Global Dynamics Division, National Center for Atmospheric Research, Boulder, \\ Colorado, USA, ${ }^{3}$ Department of Natural Resources and the Environment, University of New Hampshire, Durham, New \\ Hampshire, USA
}

Abstract Winter soil respiration at midlatitudes can comprise a substantial portion of annual ecosystem carbon loss. However, winter soil carbon dynamics in these areas, which are often characterized by shallow snow cover, are poorly understood due to infrequent sampling at the soil surface. Our objectives were to continuously measure winter $\mathrm{CO}_{2}$ flux from soils and the overlying snowpack while also monitoring drivers of winter soil respiration in a humid temperate forest. We show that the relative roles of soil temperature and moisture in driving winter $\mathrm{CO}_{2}$ flux differed within a single soil-to-snow profile. Surface soil temperatures had a strong, positive influence on $\mathrm{CO}_{2}$ flux from the snowpack, while soil moisture exerted a negative control on soil $\mathrm{CO}_{2}$ flux within the soil profile. Rapid fluctuations in snow depth throughout the winter likely created the dynamic soil temperature and moisture conditions that drove divergent patterns in soil respiration at different depths. Such dynamic conditions differ from many previous studies of winter soil microclimate and respiration, where soil temperature and moisture are relatively stable until snowmelt. The differential response of soil respiration to temperature and moisture across depths was also a unique finding as previous work has not simultaneously quantified $\mathrm{CO}_{2}$ flux from soils and the snowpack. The complex interplay we observed among snow depth, soil temperature, soil moisture, and $\mathrm{CO}_{2}$ flux suggests that winter soil respiration in areas with shallow seasonal snow cover is more variable than previously understood and may fluctuate considerably in the future given winter climate change.

\section{Introduction}

Soil respiration during winter can globally contribute 5 to $60 \%$ of the total annual carbon dioxide $\left(\mathrm{CO}_{2}\right)$ flux from soils, and as much as $90 \%$ of carbon (C) fixed during the growing season can be lost during winter [Brooks et al., 2011; Contosta et al., 2011]. Because $~ 60 \%$ of the global land base experiences seasonal snow cover [Zhang et al., 2004], winter flux of $\mathrm{CO}_{2}$ from soils to the atmosphere plays a significant role in the global C cycle.

While microbial activity can take place at temperatures as low as $-39^{\circ} \mathrm{C}$ due to the presence of liquid water in thin films surrounding soil particles [e.g., Panikov et al., 2006], most winter soil respiration occurs under an insulating snowpack that keeps soil temperatures near freezing and maintains relatively constant soil moisture [Groffman et al., 2006; Aanderud et al., 2013; Wang et al., 2013]. However, seasonal snow cover is projected to decline with climate change due to higher winter temperatures [Hayhoe et al., 2007], resulting in a shallower snowpack and a shorter snow-covered period [Dye, 2002; Déry and Brown, 2007; Lawrence and Slater, 2010]. Some of the largest projections for diminished snow cover occur in midlatitude regions such as the northeastern U.S. [Mudryk et al., 2014]. In this region, both snowfall and the number of snowcovered days have declined over the past 40 years [Burakowski et al., 2008] and are predicted to decrease further in the coming century [Hayhoe et al., 2007]. These changes in snow cover could alter the soil microclimate, modifying soil respiration rates [Groffman et al., 2006; Aanderud et al., 2013; Wang et al., 2013 ].

Relationships among snowpack, soil microclimate, and winter soil respiration in the northeastern U.S. and similar temperate regions are poorly understood. Most research on winter soil respiration in temperate biomes has consisted of infrequent measurements using chamber-based methods that excavate collars from underneath the snowpack [e.g., DeForest et al., 2006; Contosta et al., 2011], float chambers on top of the snow [e.g., Savage and Davidson, 2001; Groffman et al., 2006], or that use tall chambers that extend from the soil to above the snowpack [e.g., Schindlbacher et al., 2007]. Artifacts associated with these methods 
can overestimate or underestimate winter respiration rates [McDowell et al., 2000; Schindlbacher et al., 2007; Björkman et al., 2010], which in turn can cause errors in annual estimates of soil C losses. In addition, infrequent sampling fails to capture dynamic changes in respiration associated with episodic events such as freeze-thaw [Bubier et al., 2002].

The gradient technique offers an alternative for measuring winter soil $\mathrm{CO}_{2}$ dynamics. It quantifies $\mathrm{CO}_{2}$ concentrations at different depths within soil or different heights within the snowpack and uses Fick's law of diffusion to estimate flux [e.g., Brooks et al., 1997; Billings et al., 1998]. To date, the gradient method of calculating $\mathrm{CO}_{2}$ flux from the snowpack $\left(F_{\text {snow }}\right)$ has largely been applied in high altitude- and/or high-latitude areas characterized by deep and persistent snow cover, with only a handful of these studies making automated measurements of snow $\mathrm{CO}_{2}$ efflux [Bowling et al., 2009; Liptzin et al., 2009; Seok et al., 2009]. Only recently has the gradient technique been applied for estimating snow $\mathrm{CO}_{2}$ flux in low-elevation, temperate forest ecosystems [Suzuki et al., 2006; Seok et al., 2014]. While applications of the gradient method for measuring soil respiration are much more widespread than for determining snow $\mathrm{CO}_{2}$ flux, these studies have occurred either in areas that do not experience snow cover [Tang et al., 2003; Vargas et al., 2010] or during the growing season [Jassal et al., 2005; Riveros-Iregui et al., 2008].

Our objective was to use the gradient technique to continuously quantify winter soil $\mathrm{CO}_{2}$ dynamics and their abiotic drivers both within the soil profile and through the snowpack. For this investigation, we define $F_{\text {soil }}$ as the production of $\mathrm{CO}_{2}$ by heterotrophs and autotrophs within the soil profile, $F_{\text {soil-snow }}$ as the release of this $\mathrm{CO}_{2}$ from the soils into the overlying snow, and $F_{\text {snow }}$ as the release of $\mathrm{CO}_{2}$ from the snowpack to the atmosphere. We continuously measured these processes using the gradient technique to quantify winter soil $\mathrm{CO}_{2}$ loss in a humid temperate forest system. Here we present the first automated, simultaneous measurements of soil and snow $\mathrm{CO}_{2}$ efflux and their environmental controls in snow-covered soils during winter, both for midlatitudes and globally. These measurements are a crucial first step to understanding how rapidly fluctuating environmental conditions - which are likely to become more prevalent with climate changeaffect the loss of soil $\mathrm{CO}_{2}$ during the winter months.

\section{Methods}

\subsection{Site Description and Study Design}

Our measurements were made in an $\sim 100$ year old, even-aged mixed deciduous forest in Durham, $\mathrm{NH}\left(43.11^{\circ} \mathrm{N}\right.$, $70.95^{\circ} \mathrm{W} ; 23 \mathrm{~m}$ above sea level) dominated by red maple (Acer rubrum), red oak (Quercus rubra), and white pine (Pinus strobus). Soils are of the Hollis-Charlton complex (Hollis series: loamy, mixed, active, and mesic Lithic Dystrudepts and Charlton series: coarse-loamy, mixed, active, and mesic Typic Dystrudepts). The depth of the organic horizon is $\sim 4.4 \mathrm{~cm}$ and is $\sim 12 \%$ organic C. Texture in the upper $10 \mathrm{~cm}$ of mineral soil is sandy loam ( $67 \%$ sand, $23 \%$ silt, and $10 \%$ clay), with an average $\mathrm{pH}$ of 4.4 and average organic $\mathrm{C}$ of $3 \%$. Mean annual temperature is $\sim 8.5^{\circ} \mathrm{C}$, and average winter (December-February) temperature is $\sim 3.0^{\circ} \mathrm{C}$. Mean total precipitation (including snow water equivalent or SWE) is $\sim 1250 \mathrm{~mm}$ [Diamond et al., 2013], while mean total snowfall is $1130 \mathrm{~mm}$ [New Hampshire State Climate Office, 2014].

\subsection{Carbon Dioxide Sampling System}

Carbon dioxide was measured in both the soil profile and the overlying snowpack. Soil $\mathrm{CO}_{2}$ efflux through the snowpack $\left(F_{\text {snow }}\right)$ was estimated based on the diffusion method outlined by Seok et al. [2009]. This method consisted of installing a "snow tower" at the site. The vertical portion of the tower was made from $2.54 \mathrm{~cm}$ aluminum square and was $150 \mathrm{~cm}$ high. Crossbars consisted of $2.54 \mathrm{~cm}$ aluminum angle that were attached to the vertical at $0,20,40,60,80,100,120$, and $150 \mathrm{~cm}$. Heights were selected to sample snow $\mathrm{CO}_{2}$ concentrations at a variety of locations throughout the snowpack, from most concentrated at $0 \mathrm{~cm}$ (the snow-soil interface) to least concentrated in the atmosphere.

Each of the crossbars supported a pair of sampling inlets outfitted with $1 \mu \mathrm{m}$ mesh Acrodisc ${ }^{\circledast}$ polytetrafluoroethylene syringe filters (Pall Life Sciences, Ann Arbor, MI, USA) that kept particulates from entering the sample lines. Sample lines consisted of perfluoroalkoxy Teflon ${ }^{\oplus}$ tubing (Parker Hannifin, Cleveland, $\mathrm{OH}$, USA) with an inner diameter of $3.9 \mathrm{~mm}$ and an outer diameter of $6.4 \mathrm{~mm}$. Sample lines were each $10 \mathrm{~m}$ in length and had a total volume of $1195 \mathrm{~cm}^{3}$. 
Sampling through a pair of inlets was controlled by a Campbell Scientific CR10X Data Logger during the winter of 2013 and a Campbell Scientific CR1000 Data Logger in the winter of 2014 (Campbell Scientific, Logan, UT, USA). A Campbell Scientific SDM-CD16AC relay connected to an array of eight solenoid valves controlled the selection of pairs of inlets for sampling. Sample was transported from the tower to a LI-COR $\mathrm{LI}-840 \mathrm{CO}_{2} / \mathrm{H}_{2} \mathrm{O}$ infrared gas analyzer (LI-COR, Lincoln, NE, USA) using a KNF N86KNDCB minidiaphragm vacuum pump (KNF Neuberger Inc., Trenton, NJ, USA) with a flow rate of $1 \mathrm{~L} \mathrm{~min}^{-1}$. Because the samples were collected using paired inlets, the effective sampling rate for each inlet was $0.5 \mathrm{~L} \mathrm{~min}^{-1}$ or $500 \mathrm{~cm}^{3} \mathrm{~min}^{-1}$. Each inlet was sampled for a total of $10 \mathrm{~min}$. This time frame was determined based on Seok et al. [2009] to ensure complete flushing of sample lines before and after sampling as well as transport of interstitial gas to the analyzer during the middle $6 \mathrm{~min}$ of the sampling period. Based on Bowling et al. [2009] and Seok et al. [2014], we estimate that our system, with an effective flow rate of $0.5 \mathrm{~L} \mathrm{~min}^{-1}$ over $10 \mathrm{~min}$, sampled a sphere of gas with a $11.6 \mathrm{~cm}$ radius around inlets placed $20 \mathrm{~cm}$ apart, where the radius was $r=3 \sqrt{ }((V \times 3 / 4) / \pi)$ and $V$ was the volume of the sampled sphere of gas adjusted for a snowpack with an average porosity of 0.695 . Planar diffusion would reestablish this gradient in $t=x^{2} / 4 D$ or $(11.6 \mathrm{~cm})^{2} /\left(4 \times 0.0796 \mathrm{~cm}^{2} \mathrm{~s}^{-1}\right)=423 \mathrm{~s}$ (or $7.05 \mathrm{~min}$ ) within our $80 \mathrm{~min}$ sample cycle, where $0.0796 \mathrm{~cm}^{2} \mathrm{~s}^{-1}$ was the estimated average snow diffusion coefficient over both winters.

Samples were collected sequentially from pairs of inlets, starting at $0 \mathrm{~cm}$ height and ending at $150 \mathrm{~cm}$. Carbon dioxide concentrations were measured every $3 \mathrm{~s}$, with average values recorded every $12 \mathrm{~s}$. All eight pairs of inlets were sampled over an 80 min period, making 18 measurement cycles per day. Because $\mathrm{CO}_{2}$ concentrations did not vary substantially within paired inlets during a measurement cycle, $\mathrm{CO}_{2}$ values recorded every $12 \mathrm{~s}$ during the middle 6 min of sampling were averaged, making eight $\mathrm{CO}_{2}$ concentrations-one for each paired inlet height - per 80 min sample cycle. These eight $\mathrm{CO}_{2}$ concentrations were then used for calculating $\mathrm{CO}_{2}$ flux through the snowpack. There was nearly continuous data collection in the winter of 2013, from 4 January 2013 until snowpack disappearance on 30 March 2013. In 2014, measurements of snow $\mathrm{CO}_{2}$ concentrations were delayed until 23 January 2014 because of programming issues with the new CR1000 data logger and continued until snowpack disappearance until 4 April with a 5 day data gap in mid-February due to problems with power supply.

Fluxes of $\mathrm{CO}_{2}$ within the soil $\left(F_{\text {soil }}\right)$ were determined using the method outlined by Tang et al. [2003]. Two soil $\mathrm{CO}_{2}$ concentration depth profiles were installed at the site and were located $\sim 5 \mathrm{~m}$ from the snow tower. Soil $\mathrm{CO}_{2}$ concentrations were measured continuously with Vaisala GMT 220 series solid state infrared $\mathrm{CO}_{2}$ transmitters housed within in-soil adaptors (Vaisala Oyj, Helsinki, Finland). Sensors were installed in December 2013 but did not start recording data until 23 January 2014 due to the same programming issues outlined above. The 5 day gap in mid-February also occurred as a result of the same power issues. The $\mathrm{CO}_{2}$ sensors were installed at two depths, -5 and $-15 \mathrm{~cm}$, which were the same depths at which soil temperature and volumetric water content measurements were made (see below; negative numbers for soil depths are used throughout to differentiate from depths in the snowpack). As with snow $\mathrm{CO}_{2}$, soil $\mathrm{CO}_{2}$ concentrations were measured every $3 \mathrm{~s}$ and written every $12 \mathrm{~s}$ to the data logger. Because soil $\mathrm{CO}_{2}$ concentrations did not change substantially over subhourly time periods, data were then averaged over the entire 80 min snow tower measurement period. This resulted in 18 calculations of $F_{\text {soil }}$ per depth increment and soil profile gradient per day. Calculations of $F_{\text {soil-snow }}$ were derived from measurements of $\mathrm{CO}_{2}$ both in the snowpack and the soil (see below).

\subsection{Snowpack, Soil, and Environmental Measurements}

Soils measurements for calculating $F_{\text {soil }}$ included estimating soil porosity using soil bulk density and soil organic matter (SOM) data, which were determined previously at an ongoing research plot located $\sim 120 \mathrm{~m}$ from the site (A. Contosta unpublished data). Average bulk density and SOM between -5 and $-20 \mathrm{~cm}$ were $0.80 \mathrm{~g} \mathrm{~cm}^{-3}$ and $4.72 \%$, respectively. These were the values used to represent bulk density and SOM for the -5 to $-15 \mathrm{~cm}$ depth increment over which $\mathrm{CO}_{2}$ concentrations were measured and soil $\mathrm{CO}_{2}$ production $\left(F_{\text {soil }}\right)$ was calculated.

Additional environmental measurements for calculating $F_{\text {soil }}$ and understanding drivers of $\mathrm{CO}_{2}$ flux consisted of air temperature, ambient air pressure, soil temperature, and soil volumetric water content $(\theta)$ measured at the site. Air temperature was recorded with a Campbell Scientific 107-L30 Temperature Probe used in tandem 
with a Campbell Scientific 41303-5A Radiation Shield to prevent solar radiation loading. Ambient air pressure was recorded by the LI-COR LI-840 every $3 \mathrm{~s}$, written to the data logger every $12 \mathrm{~s}$, and correlated well with measurements of air pressure made at Thompson Farm National Oceanic and Atmospheric Administration United States Climate Reference Network site located $\sim 300 \mathrm{~m}$ away in a nearby pasture [Diamond et al., 2013]. Soil temperature and moisture were measured at $-5 \mathrm{~cm}$ with an ECH20 Soil Moisture Sensor 5TM (Decagon Devices Inc., Pullman, WA, USA). At -15 and $-30 \mathrm{~cm}$, temperature and moisture were recorded with a Campbell Scientific CS655-L $12 \mathrm{~cm}$ Soil Water Content Reflectometer. Both the near-surface and deeper soil moisture probes use time domain reflectrometry (TDR) technology and are accurate at estimating liquid water content even in partially frozen soils [Spaans and Baker, 1996]. However, TDR measurements cannot detect soil ice content, which likely occurred when soil temperatures went below $0^{\circ} \mathrm{C}$. We evaluated the phase change between liquid water and ice by modeling the relationship between soil temperature and soil $\theta$ at the threshold of $0^{\circ} \mathrm{C}$ using the logistic model:

$$
\theta_{i}=\beta_{0}+\frac{\beta_{1}}{1+e^{-\left(\beta_{2}+\beta_{3} \times T_{\text {soil }-i)}\right)}}
$$

where $\theta_{i}$ is the volumetric water content; $T_{\text {soil }}$ is the soil temperature at depth $i$; and $\beta_{0}, \beta_{1}, \beta_{2}$, and $\beta_{3}$ are the fitted parameters [Aanderud et al., 2013]. We wrote a self-starting function in R 3.0.1 [R Core Team, 2015] to fit the curve and then obtained parameter estimates and significance values using nonlinear least squares estimation $(n / s)$. The goodness of fit for the nonlinear model (i.e., whole model $r^{2}$ ) was determined by modeling measured versus predicted values. We also corrected $\theta$ measurements to include both solid and liquid phases by first determining ice content in partially frozen soil and then adding ice content to liquid $\theta$ values. Ice content in partially frozen soil was calculated following Tian et al. [2015] as

$$
\theta_{i}=\frac{\left(\theta_{l, \text { in }}-\theta_{l, \text { meas }}\right)}{\rho_{i}}
$$

where $\theta_{i}$ is the soil ice content; $\theta_{l, \text { in }}$ indicates the initial liquid water prior to freezing; $\theta_{l, \text { meas }}$ is the measured liquid in partially frozen soil, all in units of $\left(\mathrm{m}^{3} \mathrm{~m}^{-3}\right)$; and $\rho_{i}$ indicates the density of ice $\left(917 \mathrm{~kg} \mathrm{~m}^{-3}\right)$. We then added ice content to liquid water content to obtain total soil $\theta$, correcting for the density of ice relative to liquid water:

$$
\theta_{\mathrm{tot}}=\theta_{l}+\theta_{i} \times\left(\frac{917}{1000}\right)
$$

where $\theta_{\text {tot }}$ is the total water content and $\theta_{l}$ and $\theta_{i}$ indicate the liquid and ice content, respectively. Air and soil temperature and soil moisture were recorded every $10 \mathrm{~min}$. For winter of 2013, these data were not available after day of year 84 due to battery failure. Soil temperature, soil moisture, site air temperature, and ambient air pressure were averaged over the $80 \mathrm{~min}$ sampling cycle.

Additional measurements for determining $F_{\text {snow }}$ included snow temperature, depth, density, and snow water equivalent (SWE). Snow temperatures at each sampling inlet were measured using Omega Type-T thermocouples (Omega Engineering Inc., Stamford, CT, USA) sheathed in white heat-shrink tubing. Snow temperature was measured every $3 \mathrm{~s}$, averaged and logged every $12 \mathrm{~s}$, and then adjusted following Luce and Tarboton [2001] to remove large diel variation and above freezing temperatures related to erroneous corrections from the reference thermistor on the data logger face plate. As with other environmental measurements, snow temperatures were averaged over the $80 \mathrm{~min}$ sample cycle.

In addition to surface snow temperature, snow depth and density were measured daily at a snow pit located approximately $25 \mathrm{~m}$ from the tower. The presence of dense ice layers and packed, coarse granular snow layers precluded measuring at discrete intervals matching the tower heights. Total column snow depth was measured by inserting an aluminum snow tube $(61 \mathrm{~cm}$ long $\times 4.5 \mathrm{~cm} \mathrm{ID)}$ vertically into the snowpack. Snow collected inside the tube was weighed using a CCi HS-30 digital hanging scale to calculate snow density. Total SWE was determined by multiplying snow depth $\times$ density.

\subsection{Diffusion Method for Estimating $\mathrm{CO}_{2}$ Efflux}

We calculated $F_{\text {soil }}$ and $F_{\text {snow }}$ using Fick's law [e.g., Brooks et al., 1997; Billings et al., 1998]:

$$
F=-D_{s} \frac{\partial c}{\partial z}
$$


where $F$ indicates the $\mathrm{CO}_{2}$ flux $\left(\mu \mathrm{mol} \mathrm{m}{ }^{-2} \mathrm{~s}^{-1}\right), D_{s}$ is the rate of diffusion of $\mathrm{CO}_{2}$ through soils or snow $\left(\mathrm{m}^{2} \mathrm{~s}^{-1}\right)$, $\partial C$ is the concentration gradient of $\mathrm{CO}_{2}\left(\mu \mathrm{mol} \mathrm{m}{ }^{-3}\right)$, and $\partial z$ is the depth of the gradient $(\mathrm{m})$. While some of the theoretical coefficients differ in soil versus snow, the process is similar in that the density, porosity, and tortuosity of the media must be determined to estimate the diffusion of $\mathrm{CO}_{2}$ from one layer in the snow or soil to the one above it.

We determined $F_{\text {soil }}$ between -15 and $-5 \mathrm{~cm}$ depths in the soil based on Tang et al. [2003]. Deviations from that method included how we applied pressure and temperature corrections to the raw sensor output and how we estimated total soil porosity and tortuosity. Using instructions from Vaisala for GMT220 sensors, we made temperature and pressure compensations using the ideal gas law:

$$
C_{c}=C_{m}\left(\frac{T_{m} \times 1013}{P_{m} \times 298.15}\right)
$$

where $\mathrm{C}$ is the $\mathrm{CO}_{2}$ mixing ratio in ppm; $T$ stands for soil temperature in $\mathrm{K} ; P$ indicates the ambient pressure in $\mathrm{hPa}$; and $c$ and $m$ stand for the corrected and measured values of $C, T$, and $P$, respectively. To calculate porosity, we estimated weighted average density of both minerals and SOM for -5 to $-20 \mathrm{~cm}$ following Davidson et al. [2006b] and Moldrup et al. [2000] instead of using the assumed particle density of $2.65 \mathrm{~g} \mathrm{~cm}^{-3}$ for mineral soil. We then corrected porosity to account for the presence of coarse rocks in the soil bed volume that were not included in our bulk density analyses. The presence of coarse rocks ( $>2 \mathrm{~mm}$ ) in New England glacial tills such as those at our site can occupy 20 to $30 \%$ of the soil bed volume [Kulmatiski et al., 2003; Davidson et al., 2006b]. This, in turn, impacts the total pore space through which air and water can move, ultimately affecting estimates of diffusion through the soil profile. To account for this, we adjusted porosity downward as

$$
\phi_{\text {corr }}=\phi-(\phi \times \mathrm{RF})
$$

where $\phi_{\text {corr }}$ is the corrected porosity, $\phi$ is the soil porosity determined from measured bulk density and SOM, and $\mathrm{RF}$ is an assumed rock fraction of $20 \%$. While this assumed rock fraction may be greater or less than the actual fraction of coarse rocks at our site, the resulting $\phi_{\text {corr }}$ value obtained from equation (6), 0.55 , produced much more realistic estimates of diffusion and $\mathrm{CO}_{2}$ flux than $\phi$ alone. We then estimated soil tortuosity with the Moldrup et al. [1997] model:

$$
\xi=\left(\phi_{\text {corr }}-\theta_{\text {tot }}\right)\left(\frac{\phi_{\text {corr }}-\theta_{\text {tot }}}{\phi}\right)^{\frac{12-m}{3}}
$$

where $\xi$ is the gas tortuosity, $\theta_{\text {tot }}$ is the total volumetric water content (liquid and ice), and $m$ is a constant that equals 3 . We chose this tortuosity model because it produced more plausible estimates of diffusion in our high-porosity soils as opposed to models such as Millington and Quirk [1961] and Moldrup et al. [2000], which can overestimate diffusion for highly porous substrates [lyamada and Hasegawa, 2005; Pingintha et al., 2010].

We determined $F_{\text {snow }}$ for three depth increments in the snowpack: 0 to $20 \mathrm{~cm}, 0$ to $40 \mathrm{~cm}$, and 20 to $40 \mathrm{~cm}$ following Seok et al. [2009], as these were the only depths that were regularly covered with snow. The only differences were that we used the more general Duplessis and Masliyah [1991] method for determining snowpack tortuosity instead of the more site specific method that Seok et al. [2009] employed. We also used weighted average density, porosity, and tortuosity values for the entire snowpack as opposed to determining these values for each sampling height on the tower. Weights were the relative percentages that each layer in the profile contributed to the total depth.

Given the difficulties of estimating diffusion across an extremely porous and heterogeneous litter layer [Maier and Schack-Kirchner, 2014], we estimated the flux of $\mathrm{CO}_{2}$ leaving the soil and entering the snowpack $\left(F_{\text {soil-snow }}\right)$ as

$$
F_{\text {soil-snow }}=\frac{z_{i+1} F_{i}-z_{i} F_{i+1}}{z_{i+1}-z_{i}}
$$

where $F_{\text {soil-snow }}$ is the soil respiration in units of $\mu \mathrm{mol} \mathrm{m}^{-2} \mathrm{~s}^{-1}$ and $F_{i}$ and $F_{i+1}$ are the $\mathrm{CO}_{2}$ effluxes at depths $z_{i}$ and $z_{i+1}$ [e.g., Hirano et al., 2003; Vargas et al., 2010]. Where other studies extrapolate $\mathrm{CO}_{2}$ efflux from the soil 
from two to three estimates of $F_{\text {soil }}$ within the soil profile [Maier and Schack-Kirchner, 2014], equation (8) interpolates this flux between $F_{\text {snow }}\left(F_{i}\right)$ and $F_{\text {soil }}\left(F_{i+1}\right)$.

We calculated the total seasonal flux of $F_{\text {soil, }} F_{\text {soil-snow, }}$ and $F_{\text {snow }}$ by determining daily average fluxes, scaling them to $24 \mathrm{~h}$ periods, and then adding them together for the duration of each sample year (2013 and 2014). Data gaps between daily fluxes were filled with linear interpolation. Uncertainty was estimated by performing the same calculations on the standard deviation of daily average fluxes.

\subsection{Statistical Analysis}

We used correlation analysis to examine pairwise relationships between climatic, soil, and $\mathrm{CO}_{2}$ variables and multiple regression to explore the sensitivity of $F_{\text {soil, }} F_{\text {snow, }}$ and $F_{\text {soil-snow }}$ to simultaneous environmental fluctuations in temperature, moisture, and snowpack dynamics. All statistics were conducted in $\mathrm{R}$ 3.0.1 $[R$ Core Team, 2015].

Correlation analysis examined pairwise relationships between climatic, soil, and $\mathrm{CO}_{2}$ variables. Data were snow depth; SWE; air temperature; snow temperature; soil temperature; $\theta$; snow and soil $\mathrm{CO}_{2}$ concentrations; and $F_{\text {soil }}, F_{\text {soil-snow, }}$ and $F_{\text {snow. }}$. We used snow temperatures at $0 \mathrm{~cm}$ as indicative of temperatures within the snowpack. For soil temperature and moisture, we evaluated measurements from $-5,-15$, and $-30 \mathrm{~cm}$, averaging by depth for the entire site. We calculated site averages of $F_{\text {soil, }}$ site averages of $F_{\text {soil-snow, }}$ and fluxes determined for the 0 to $20 \mathrm{~cm}$ depth increment for $F_{\text {snow. }}$. Finally, we calculated daily averages of each variable sampled at subdaily time scales. This allowed us to integrate measurements made on a daily time step with more frequently sampled variables. It also reduced noise in the data set resulting from diel variation in $\mathrm{CO}_{2}$ dynamics and their environmental drivers.

We used multiple regression to better understand the sensitivity of $F_{\text {soil, }} F_{\text {soil-snow, }}$ and $F_{\text {snow }}$ to simultaneous environmental fluctuations in temperature, moisture, and snowpack dynamics. Data were the same as for correlation analysis. Prior to performing the multiple regressions, the entire data set was examined for outliers, homogeneity of variance, normality, collinearity, potential interactions, and independence of observations [Zuur et al., 2010]. Using this protocol, we developed three multiple regression models:

$$
\begin{gathered}
F_{\text {soil }} \sim \beta+\left[k_{1} \times T_{\text {soil }(-30 \mathrm{~cm})}\right]+\left[k_{2} \times \theta_{(-30 \mathrm{~cm})}\right]+\left(k_{3} \times \mathrm{SWE}\right) \\
F_{\text {soil-snow }} \sim \beta+\left[k_{1} \times T_{\text {soil }(-15 \mathrm{~cm})}\right]+\left[k_{2} \times \theta_{(-15 \mathrm{~cm})}\right]+\left(k_{3} \times \mathrm{SWE}\right) \\
F_{\text {snow }} \sim\left[\beta_{1} e^{\left.k_{1} T_{\text {soil }(-5} \mathrm{cm}\right)}\right]+\left\{\beta_{2}+\left[k_{2} \times \theta_{(-15 \mathrm{~cm})}\right]+\left(k_{3} \times \mathrm{SWE}\right)\right\}
\end{gathered}
$$

where $\beta$ denotes the model intercept for equations (9) and (10); $\beta_{1}$ and $\beta_{2}$ indicate the intercepts for the exponential and linear portions of the model for equation $(11) ; k_{1}-k_{3}$ are the slopes associated with predictor variables $T_{\text {soil, }} \theta$, and SWE, respectively; $T_{\text {soil }}(-5,-15$, or $-30 \mathrm{~cm})$ stands for soil temperatures at $-5,-15$, and $-30 \mathrm{~cm}$ depths; $\theta_{(-5,-15}$, or $\left.-30 \mathrm{~cm}\right)$ is the soil moisture at $-5,-15$, and $-30 \mathrm{~cm}$ in the soil profile; and SWE denotes the snow water equivalent. Model terms were selected due to lack of collinearity with other independent variables, which was assessed by calculating the variance inflation factors of each variable relative to all of the other potential independent variables [Zuur et al., 2010]. Within each model, soil temperature and moisture variables also represented soil conditions below the layer in which the flux was calculated. Models 9 and 10 were fit using generalized least squares $(\mathrm{g} / \mathrm{s})$ in the $n / m e$ package [Pinhiero et al., 2009], while model 11 was fit with nonlinear least squares $(\mathrm{n} / \mathrm{s})$ to depict the exponential relationship between $T_{\text {soil }}(-5 \mathrm{~cm})$ and $F_{\text {snow }}$ using the same approach as for equation (1). Significant effects were then determined with a backward selection procedure described by Zuur et al. [2009]. Model-level $p$ and $r^{2}$ values typically reported for regressions were not available for either $\mathrm{g} / \mathrm{s}$ or $\mathrm{n} / \mathrm{s}$. Instead, these statistics were determined by fitting predicted versus observed $F_{\text {soil, }} F_{\text {soil-snow, }}$ and $F_{\text {snow }}$ values. For models 9 and 10 , the relative contribution of each independent variable in the final model to the whole model $r^{2}$ was determined with the $I m g$ function in the relaimpo package [Grömping, 2006; Berryman et al., 2015]. Obtaining such partial regression statistics for the nonlinear model was not possible. Thus, we also determined the relative contribution of each model term to overall model fit by omitting each independent variable in turn and comparing the full to the reduced model using Akaike information criterion [Burnham and Anderson, 2002]. Large increases in Akaike information criterion (AIC) in the reduced compared to the full model indicated that the dropped variable contributed substantially to model fit. 

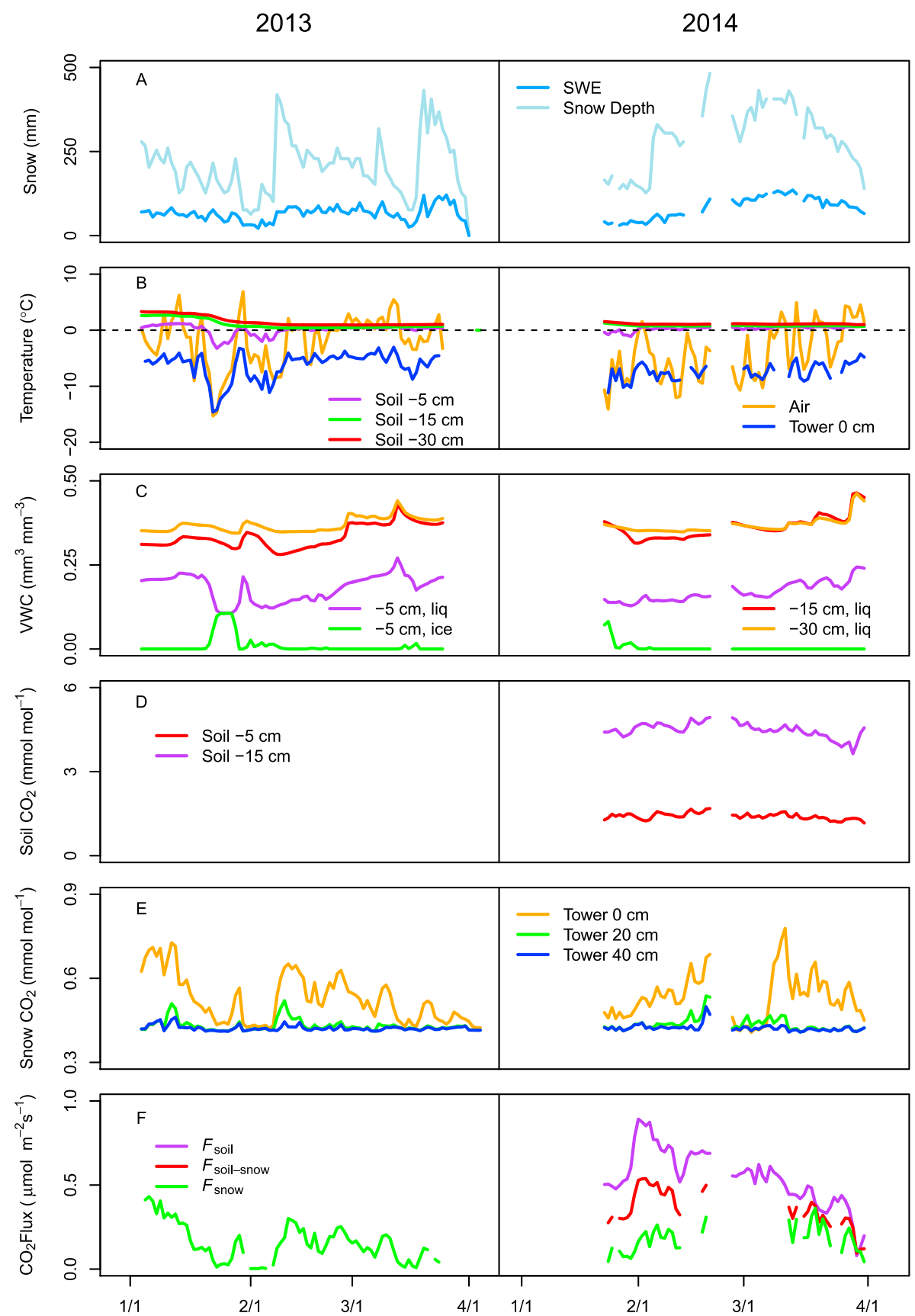

Figure 1. (a) Snow water equivalent (SWE) and snow depth; (b) air temperature, thermocouple temperature at $0 \mathrm{~cm}$ on the snow tower, and soil temperatures at $-5,-15$, and $-30 \mathrm{~cm}$ depths; (c) liquid soil water and ice content at $-5 \mathrm{~cm}$ and liquid soil water content at -15 and -30 depths; (d) soil $\mathrm{CO}_{2}$ concentrations at -5 and $-15 \mathrm{~cm}$ depth; (e) $\mathrm{CO}_{2}$ concentrations at 0,20 , and $40 \mathrm{~cm}$ on the snow tower; and (f) rates of $F_{\text {soil }}, F_{\text {soil-snow, }}$ and $F_{\text {snow. }}$. Data are daily average values, except Figure 1a, which shows daily total values.

\section{Results}

\subsection{Environmental Conditions}

Environmental conditions (snow depth, SWE, air, and snow temperatures, and soil moisture) generally showed high temporal variability (Figure 1), and many environmental drivers were correlated with one another (Table S1 in the supporting information). Seasonal snow cover was dynamic in both winters, with snow depth and SWE increasing following snowfall and then rapidly declining with melt, sublimation, 


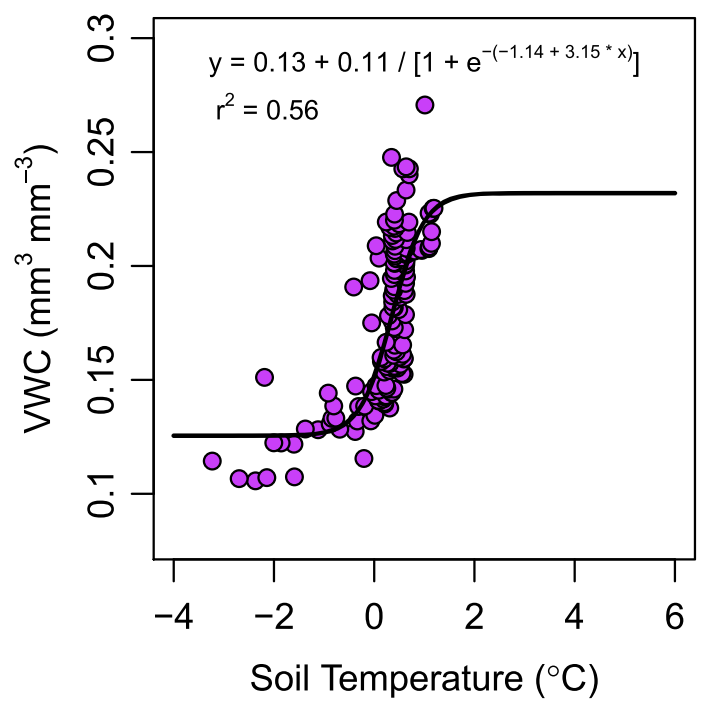

Figure 2. Logistic model of the relationship between soil temperature and soil volumetric water content $(\theta)$ at $-5 \mathrm{~cm}$ depth (equation (1)). This relationship describes a phase change between ice and liquid water as temperatures cross the threshold from below to above $0^{\circ} \mathrm{C}$. Fitted parameters for the logistic model are indicated on the figure. The $r^{2}$ statistic shows the goodness of fit between observed and fitted values. Data are daily average values.

and/or deeper snowpacks (Table S1)
On six separate instances throughout the study period, soil temperatures at $-5 \mathrm{~cm}$ depth fell below $0^{\circ} \mathrm{C}$ when a period of snowpack decline was followed by cold air temperatures, resulting in soil freezing. During these periods of soil freezing, temperatures at $-5 \mathrm{~cm}$ were as low as $-3.2^{\circ} \mathrm{C}$. Deeper in the soil profile at -15 and $-30 \mathrm{~cm}$, temperatures were higher, averaging 0.9 and $1.4^{\circ} \mathrm{C}$, respectively. They were also less variable, gradually decreasing from the onset of the snowpack to the spring melt period (Figure 1b).

Unlike soil temperature, which only fluctuated at $-5 \mathrm{~cm}, \theta$ was dynamic at all three depths $(-5,-15$, and $-30 \mathrm{~cm}$; Figure 1c). Although $\theta$ was lowest at $-5 \mathrm{~cm}$ depth, shifts in surface moisture may have propagated through the soil profile to drive variations in water content at -15 and $-30 \mathrm{~cm}$; both of which were highly correlated with $\theta$ at $-5 \mathrm{~cm}(r=0.60, p=0.00$ for $\theta$ at $-15 \mathrm{~cm} ; r=0.71, p=0.00$ for $\theta$ at $-30 \mathrm{~cm}$; Table S1). Changes in $\theta$ at $-5 \mathrm{~cm}$ were strongly nonlinear according to the fitted logistic regression $\left(r^{2}=0.56\right.$; equation (1)) and likely represented a phase change from ice to liquid water as surface temperatures crossed a threshold from below to above $0^{\circ} \mathrm{C}$ (Figure 2). Soil ice content at $-5 \mathrm{~cm}$ was minimal over both 2013 and 2014, averaging only $0.007 \mathrm{~mm}^{3} \mathrm{~mm}^{-3}$ during the entire sampling period. Soil ice was most prominent in late January 2013 when relatively shallow snow (Figure 1a) and very low temperatures (Figure 1b) resulted in a soil ice content of $0.11 \mathrm{~mm}^{3} \mathrm{~mm}^{-3}$, which was equivalent to liquid water content at that time (Figure 1c). In addition to soil temperature driving soil moisture dynamics, $\theta$ was also significantly positively correlated with SWE and air temperature, such that soils were generally wetter with deeper snowpacks and higher atmospheric temperatures (Table S1).

\subsection{Carbon Dioxide Concentrations}

Snow and soil $\mathrm{CO}_{2}$ concentrations fluctuated over time and were correlated with environmental conditions (Table $\mathrm{S} 1$ and Figure 1). Soil $\mathrm{CO}_{2}$ levels in 2014 were higher than snow $\mathrm{CO}_{2}$ concentrations and increased with depth from -5 to $-15 \mathrm{~cm}$ (Figure $1 \mathrm{~d}$ ). Soil $\mathrm{CO}_{2}$ concentrations were positively correlated with snow depth and were negatively correlated with soil temperature and soil moisture (Table S1). The negative correlations between moisture and soil $\mathrm{CO}_{2}$ content were particularly evident from 19 to 29 March 2014 when $\mathrm{CO}_{2}$ concentrations rapidly declined as $\theta$ increased during the onset of spring snowmelt (Figures $1 \mathrm{c}$ and $1 \mathrm{~d}$ ).

Snow $\mathrm{CO}_{2}$ concentrations were highest and most variable at the snow-soil interface $(0 \mathrm{~cm})$, were substantially lower and less dynamic even $20 \mathrm{~cm}$ above the soil surface, and were as much as 10 times lower than $\mathrm{CO}_{2}$ 
Table 1. Correlation Coefficients $(r)$ and $p$ Values Indicating the Significance of Correlations Between $P_{\text {soil }}, F_{\text {soil, }}$ and $F_{\text {snow }}$ and Environmental Variables ${ }^{a}$

\begin{tabular}{|c|c|c|c|c|c|c|}
\hline & \multicolumn{2}{|c|}{$F_{\text {soil }}$} & \multicolumn{2}{|c|}{$F_{\text {soil-snow }}$} & \multicolumn{2}{|c|}{$F_{\text {snow }}$} \\
\hline & $P$ & $r$ & $p$ & $r$ & $p$ & $r$ \\
\hline Snow depth & 0.87 & -0.01 & 0.05 & 0.14 & 0.00 & 0.44 \\
\hline SWE & 0.00 & -0.37 & 0.00 & -0.27 & 0.00 & 0.37 \\
\hline Air $T$ & 0.00 & -0.30 & 0.20 & -0.09 & 0.00 & 0.33 \\
\hline Snow $T_{(0 \mathrm{~cm})}$ & 0.00 & -0.33 & 0.02 & -0.17 & 0.00 & 0.33 \\
\hline Soil $T_{(-5 \mathrm{~cm})}$ & 0.00 & -0.21 & 0.98 & 0.00 & 0.00 & 0.59 \\
\hline Soil $T(-15 \mathrm{~cm})$ & 0.98 & 0.00 & 0.22 & -0.09 & 0.00 & 0.38 \\
\hline Soil $T(-30 \mathrm{~cm})$ & 0.11 & -0.11 & 0.01 & -0.19 & 0.00 & 0.34 \\
\hline$\theta_{\text {liq }(-5 \mathrm{~cm})}$ & 0.00 & -0.79 & 0.00 & -0.63 & 0.00 & 0.21 \\
\hline$\theta_{\text {ice }}(-5 \mathrm{~cm})$ & 0.71 & -0.03 & 0.05 & -0.14 & 0.00 & -0.38 \\
\hline$\theta_{\text {tot }(-5 \mathrm{~cm})}$ & 0.00 & -0.82 & 0.00 & -0.73 & 0.97 & 0.00 \\
\hline$\theta_{\text {liq }}(-15 \mathrm{~cm})$ & 0.00 & -0.91 & 0.00 & -0.83 & 0.00 & -0.23 \\
\hline$\theta_{\text {liq }}(-30 \mathrm{~cm})$ & 0.00 & -0.83 & 0.00 & -0.77 & 0.00 & -0.29 \\
\hline Soil $\mathrm{CO}_{2}(-5 \mathrm{~cm})$ & 0.00 & 0.41 & 0.00 & 0.46 & 0.00 & 0.35 \\
\hline Soil $\mathrm{CO}_{2}(-15 \mathrm{~cm})$ & 0.00 & 0.66 & 0.00 & 0.66 & 0.00 & 0.21 \\
\hline Snow $\mathrm{CO}_{2}(0 \mathrm{~cm})$ & 0.09 & 0.12 & 0.00 & 0.43 & 0.00 & 0.95 \\
\hline Snow $\mathrm{CO}_{2}(20 \mathrm{~cm})$ & 0.00 & 0.44 & 0.00 & 0.50 & 0.00 & 0.45 \\
\hline Snow $\mathrm{CO}_{2}(40 \mathrm{~cm})$ & 0.00 & 0.41 & 0.00 & 0.44 & 0.00 & 0.44 \\
\hline$F_{\text {soil }}$ & 1.00 & 1.00 & 0.00 & 0.91 & 0.06 & 0.13 \\
\hline$F_{\text {soil-snow }}$ & 0.00 & 0.91 & 1.00 & 1.00 & 0.00 & 0.52 \\
\hline$F_{\text {snow }}$ & 0.06 & 0.13 & 0.00 & 0.52 & 1.00 & 1.00 \\
\hline
\end{tabular}

${ }^{\mathrm{a}}$ The full matrix showing correlations and $p$ values for each pair of environmental variables is located in Table S1 in the supporting information. Significant correlation coefficients are in bold type.

concentrations in the soil (Figure 1e). Although snow periodically covered the sample inlet at $40 \mathrm{~cm}, \mathrm{CO}_{2}$ concentrations at $40 \mathrm{~cm}$ were comparable to atmospheric values. Snow $\mathrm{CO}_{2}$ followed a similar pattern as snow depth and SWE, increasing with greater snow depth and SWE and decreasing with snowpack disappearance (Table S1). An exception was on 30 January 2013 when snow $\mathrm{CO}_{2}$ concentrations were high despite a snowpack that was only $150 \mathrm{~mm}$ deep. This anomaly may have occurred due to a pulse of $\mathrm{CO}_{2}$ releasing from soil through the snowpack as soils rapidly warmed following a prolonged freeze event [e.g., Bubier et al., 2002] (Figures $1 \mathrm{~b}$ and $1 \mathrm{e}$ ). Snow $\mathrm{CO}_{2}$ concentrations typically increased with higher soil temperatures, as indicated by the strong, positive correlations between snow $\mathrm{CO}_{2}$ at 0,20 , and $40 \mathrm{~cm}$ and soil temperatures at all depths. However, snow $\mathrm{CO}_{2}$ levels decreased with increasing $\theta$ at -15 and $-30 \mathrm{~cm}$ (Table S1).

\subsection{Soil and Snow $\mathrm{CO}_{2}$ Fluxes}

The flux of $\mathrm{CO}_{2}$ within the soil $\left(F_{\text {soil }}\right)$ was determined with soil $\mathrm{CO}_{2}$ concentrations at -5 and $-15 \mathrm{~cm}$ depths (Figure 1d). Soil $\mathrm{CO}_{2}$ flux was higher than rates of both $F_{\text {soil-snow }}$ and $F_{\text {snow }}$ averaging $0.53 \mu \mathrm{mol} \mathrm{CO}_{2} \mathrm{~m}^{-2} \mathrm{~s}^{-1}$ during the winter of 2014 (Figure 1f). We observed the highest rates of $F_{\text {soil }}$ on 4 February 2014 when both the snowpack and SWE had not yet reached their seasonal maximum. Soil $\mathrm{CO}_{2}$ flux may have reached its highest value earlier in the season because temperatures deeper in the soil profile were higher at that time. Air, snow, and surface soil temperatures were also lower, and soils were generally drier. Pairwise correlations illustrate the role that environmental conditions may have played in driving $F_{\text {soil }}$ dynamics; $F_{\text {soil }}$ was inversely related to SWE, air, snow, soil temperatures at $-5 \mathrm{~cm}$, and soil $\theta$ at all depths (Table 1). The negative correlations between $F_{\text {soil }}$ and air, snow, and surface soil temperatures were likely due to warmer conditions resulting in snowmelt and soil thaw; both of which increased $\theta$ throughout the profile. Backward selection of our initial multiple regression model (equation (9)) produced a final model with soil temperature at $-30 \mathrm{~cm}(t=-4.63$, $p<0.0001)$, soil $\theta$ at $-30 \mathrm{~cm}(t=-13.92, p<0.0001)$, and SWE $(t=-5.34, p<0.0001)$ as significant drivers of $F_{\text {soil }}$ (whole model $r^{2}=0.81$; Figure 3). Partitioning the relative contribution of each model term to the total explained variance indicated that $\theta$ at $-30 \mathrm{~cm}$ exerted the strongest influence on $F_{\text {soil }}\left(r^{2}=0.66\right)$, followed by SWE $\left(r^{2}=0.11\right)$, and finally by soil temperature at $-30 \mathrm{~cm}\left(r^{2}=0.04\right.$; Table 2). Comparing the final model to reduced models in which each predictor was omitted in turn showed a similar pattern; AIC increased most when $\theta$ at $-30 \mathrm{~cm}$ was dropped from the model, followed by SWE, and the smallest change when soil temperature at $-30 \mathrm{~cm}$ was removed (Table 2). 

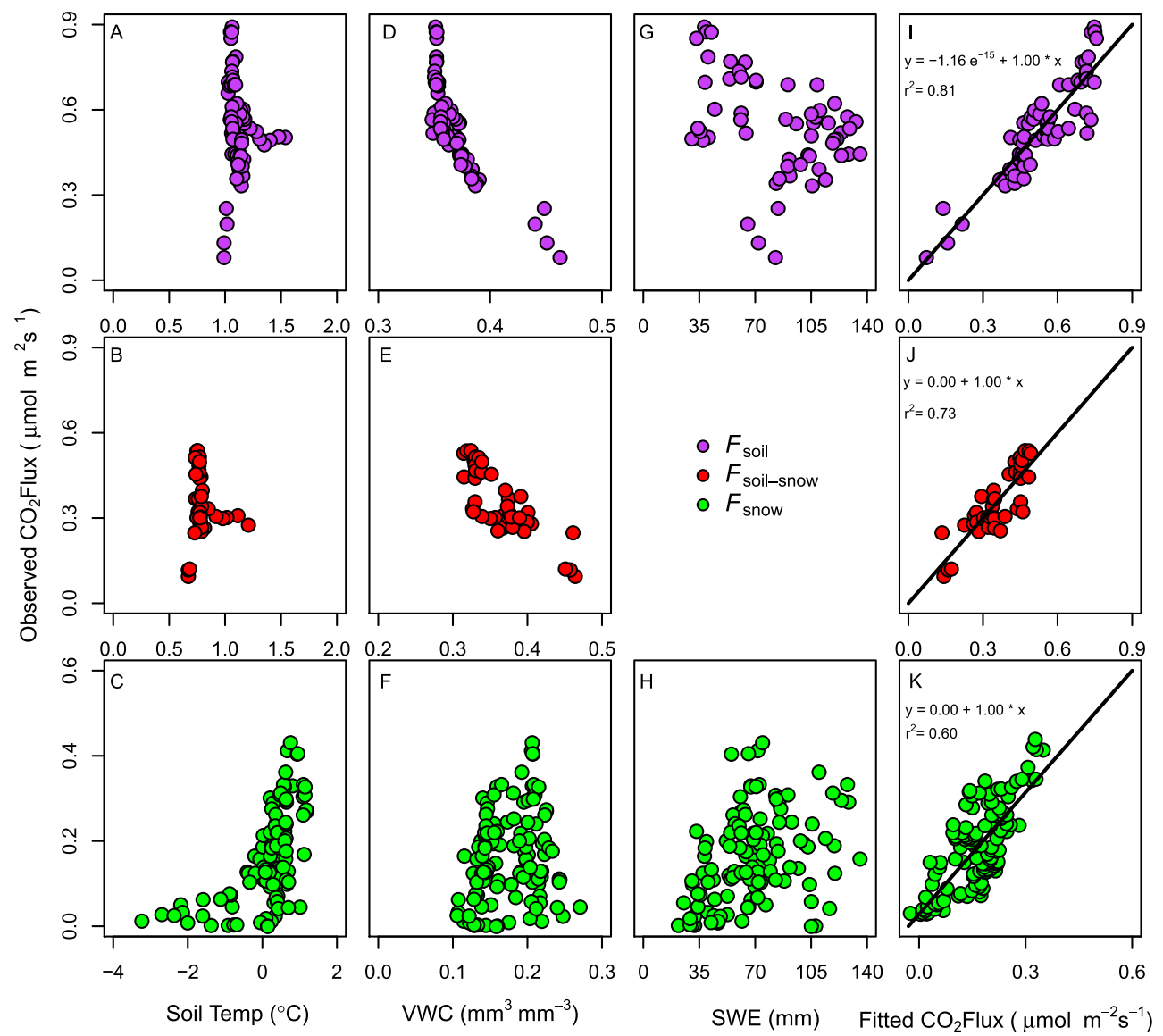

Figure 3. Scatterplots of the correlations between $\mathrm{CO}_{2}$ efflux and environmental drivers that were identified as significant predictors of $\mathrm{CO}_{2}$ flux in multiple regression modeling (equations (9)-(11)) and the overall fit of the multiple regression models as compared to observed values. Correlations include (a) $F_{\text {soil }}$ and soil temperature at $-30 \mathrm{~cm}$, (b) $F_{\text {soil-snow }}$ and soil temperature at $-15 \mathrm{~cm}$, (c) $F_{\text {snow }}$ and soil temperature at $-5 \mathrm{~cm}$, (d) $F_{\text {soil }}$ and volumetric water content (VWC) at $-30 \mathrm{~cm}$, (e) $F_{\text {soil-snow }}$ and VWC at $-15 \mathrm{~cm}$, (f) $F_{\text {snow }}$ and VWC at $-5 \mathrm{~cm},(\mathrm{~g}) F_{\text {soil }}$ and snow water equivalent (SWE), and (h) $F_{\text {snow }}$ and SWE. There is no scatterplot showing the correlation between $F_{\text {soil-snow }}$ and SWE as this was not a significant model term in the multiple regression model (equation (10)). Regression fits include predicted versus observed values

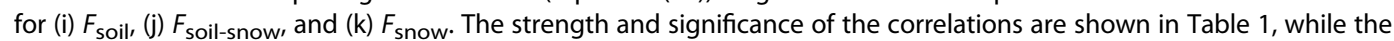
results from the multiple regression models are in Table 2 . Data are average daily values.

We calculated the efflux of $\mathrm{CO}_{2}$ out of the soil $\left(F_{\text {soil-snow }}\right)$ by interpolating between rates of $F_{\text {soil }}$ and $F_{\text {snow }}$ (Figure 1f). At $0.36 \mu \mathrm{mol} \mathrm{CO} \mathrm{m}^{-2} \mathrm{~s}^{-1}$, average seasonal values for $F_{\text {soil-snow }}$ were lower than those of $F_{\text {soil- }}$. Soil-to-snow $\mathrm{CO}_{2}$ flux followed a similar temporal trend as $F_{\text {soil }}$. Also like $F_{\text {soil, }} F_{\text {soil-snow }}$ was negatively correlated with SWE, air and snow temperatures, and soil liquid $\theta$ at all depths in the soil profile (Table 1). Multiple regression modeling (equation (10)) indicated that soil temperature at $-15 \mathrm{~cm}(t=-2.91, p=0.006)$ and $\theta$ at $-15 \mathrm{~cm}(t=-10.59, p<0.0001)$ were the best predictors for $F_{\text {soil-snow }}$ (whole model $r^{2}=0.73$; Figure 3 ). Post hoc testing of model terms indicated that $\theta$ at $-15 \mathrm{~cm}$ depth accounted for $70 \%$ of the variation in the final model while soil temperature at $-15 \mathrm{~cm}$ explained $3 \%$ (Table 2). Evaluation of model terms using AIC demonstrated a similar phenomenon. The AIC statistic increased substantially when $\theta$ at $-15 \mathrm{~cm}$ was removed from the model, indicating the strong effect of this term on overall model fit. By contrast, AIC increased very little when soil temperature at $-15 \mathrm{~cm}$ was removed.

We calculated snow $\mathrm{CO}_{2}$ flux ( $F_{\text {snow }}$ ) at three depth increments of snow $\mathrm{CO}_{2}$ concentrations, starting above the soil surface and extending up into the snowpack: 0 to $20 \mathrm{~cm}, 20$ to $40 \mathrm{~cm}$, and across the entire snow depth profile $\left(0\right.$ to $40 \mathrm{~cm}$; Figure 1f). Fluxes were highest when calculated with $\mathrm{CO}_{2}$ concentrations from the 0 to $20 \mathrm{~cm}$ increment, were lowest from the 20 to $40 \mathrm{~cm}$ depth increment, and in between when determined across the entire profile from 0 to $40 \mathrm{~cm}$. Over both winters, average $F_{\text {snow }}$ values were $0.16,0.02$, and 


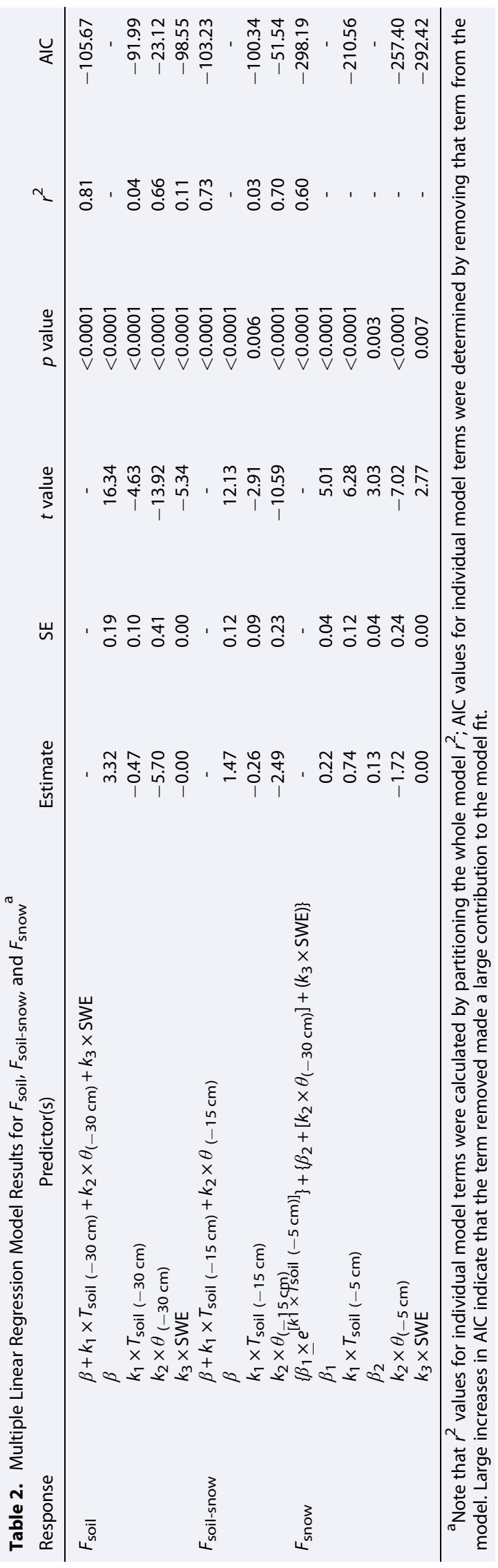

$0.11 \mu \mathrm{mol} \mathrm{CO} \mathrm{m}^{-2} \mathrm{~s}^{-1}$, respectively, for the 0 to 20,20 to 40 , and 0 to $40 \mathrm{~cm}$ increments. The gaps in flux data for 2014 resulted from power supply issues, lack of data from the $0 \mathrm{~cm}$ inlet on the snow tower, and gaps in snow measurements.

Across all snow $\mathrm{CO}_{2}$ profile increments, $F_{\text {snow }}$ was on average higher and less variable in 2014 than during the preceding year. This may have resulted from the deeper snowpack in 2014, as $F_{\text {snow }}$ tended to increase with snow height and SWE (Table 1). In addition to snowpack dynamics, $F_{\text {snow }}$ was positively correlated with air temperature, soil temperature at all three depths, $\theta$ at $-5 \mathrm{~cm}$, and soil $\mathrm{CO}_{2}$ concentrations. It was inversely related to ice content at $-5 \mathrm{~cm}$ and liquid $\theta$ at -15 and $-30 \mathrm{~cm}$ depths (Table 1). The multiple regression model that best explained variation in $F_{\text {snow }}$ across the entire data set (equation (11)) indicated that soil temperature at $-5 \mathrm{~cm}$ $(t=6.28, p<0.0001)$, soil $\theta$ at $-5 \mathrm{~cm}(t=-7.02$, $p<0.0001)$, and SWE $(t=2.77, p=0.007)$ were all significant predictors (whole model $r^{2}=0.60$; Figure 3). Among model terms, soil temperatures at $-5 \mathrm{~cm}$ depth exerted the greatest influence on $F_{\text {snow, }}$ followed by $\theta$ at $-5 \mathrm{~cm}$, and finally by SWE as indicated by relative changes in AIC when comparing the full model to reduced models that dropped each of these predictors in turn (Table 2).

Total seasonal fluxes were highest for $F_{\text {soil }}$ followed by $F_{\text {soil-snow }}$ and then by $F_{\text {snow }}$ (Table 3). However, the combination of total winter fluxes for $F_{\text {soil-snow }}$ and $F_{\text {snow, }} \quad 38.8 \mathrm{~g} \mathrm{CO}_{2}-\mathrm{C} \mathrm{m}^{-2}$ winter ${ }^{-1}$, was comparable to the total winter flux of $F_{\text {soil, }}$ $40.0 \mathrm{~g} \mathrm{CO}_{2}-\mathrm{C} \mathrm{m}^{-2}$ winter ${ }^{-1}$. Calculated total $F_{\text {snow }}$ values were similar between 2013 and 2014 and were $\sim 12.5 \mathrm{~g} \mathrm{CO}_{2}-\mathrm{C} \mathrm{m}^{-2}$ winter ${ }^{-1}$.

\section{Discussion}

To our knowledge, this study is the first to simultaneously determine $F_{\text {soill }}, F_{\text {soil-snow, }}$ and $F_{\text {snow }}$ and their environmental drivers using automated, continuous measurements. Our data indicate that surface soil temperature and subsurface soil moisture $(\theta)$ availability were the primary drivers of winter soil $\mathrm{CO}_{2}$ dynamics. The relative importance of these drivers varied with depth, such that $\theta$ strongly influenced $\mathrm{CO}_{2}$ flux from deeper in the soil profile while surface soil temperature primarily controlled $\mathrm{CO}_{2}$ flux through the snowpack. The dominant role that $\theta$ played in inhibiting winter soil $\mathrm{CO}_{2}$ flux departs from prior research showing that higher moisture generally 


\begin{tabular}{|c|c|c|c|}
\hline Year & $F_{\text {soil }}$ & $F_{\text {soil-snow }}$ & $F_{\text {snow }}$ \\
\hline 2013 & - & - & $12.5 \pm 2.8$ \\
\hline 2014 & $40.0 \pm 1.6$ & $26.0 \pm 1.8$ & $12.8 \pm 3.1$ \\
\hline
\end{tabular}

${ }^{a}$ Note that fluxes were determined for 85 and 71 days of continuous sampling for winters of 2013 and 2014, respectively. The plus-minus sign indicates 1 standard deviation.

increases winter soil C loss [Liptzin et al., 2009; Hirano, 2014; Schindlbacher et al., 2014] except during snowmelt when very wet to saturated conditions can inhibit $\mathrm{CO}_{2}$ flux [Liptzin et al., 2009; Brooks et al., 2011]. The differential response of soil respiration to $\theta$ versus temperature is also unique. Although previous studies have demonstrated that relative roles of soil moisture and temperature in driving $\mathrm{CO}_{2}$ flux across landscape gradients of moisture availability [Riveros-Iregui et al., 2012; Knowles et al., 2015; Stielstra et al., 2015], we report a similar phenomenon within single soil-to-snow profile. The relative roles that temperature and moisture played in regulating winter soil respiration are especially relevant given that they were mediated by changes in air temperature and snow depth-both of which are predicted to change in the future. Overall, our results carry important implications for understanding and modeling winter soil respiration given predicted changes in seasonal snow cover-and thus winter soil microclimate-both in temperate areas and globally.

We observed fluctuating surface soil temperatures that likely resulted from snowpack accumulation and ablation throughout the winter. These changes in surface soil temperatures-particularly above and below freezing -also resulted in nonlinear and dynamic shifts in soil $\theta$ at $-5 \mathrm{~cm}$ depth (Figure 2). Variation in surface soil temperature and attendant changes in liquid water availability may partially explain the strong relationship we observed between surface soil temperature and snow $\mathrm{CO}_{2}$ flux, assuming that this flux represents near-surface soil microbial processes. Other researchers have reported bursts of respiration during thaw cycles, such as the one we noted on 30 January 2013, and have cited a combination of high-temperature sensitivity, a flush of labile $C$, and removal of water limitations as soils crossed a threshold from under to over $0^{\circ} \mathrm{C}$ [Bubier et al., 2002; Aanderud et al., 2013]. By contrast, the lower rates of $F_{\text {snow }}$ we observed at below freezing temperatures may have arisen from a slowing of biological activity, microbial cell lysis, and/or a shortage of liquid water.

Although soil temperature explained significant variation in $F_{\text {snow, }}$ it did not exert strong control on $\mathrm{CO}_{2}$ fluxes within the soil profile. This may have been related to the fact that soil temperatures at -15 and $-30 \mathrm{~cm}$ depth did not vary enough to alter $\mathrm{CO}_{2}$ flux rates. In 2014 , the year in which we measured $F_{\text {soil }}$ and $F_{\text {soil-snow, }}$ the range of soil temperatures at depth spanned only $1^{\circ} \mathrm{C}$, from 0.5 to $1.5^{\circ} \mathrm{C}$. However, while soil temperatures at -15 and $-30 \mathrm{~cm}$ were fairly constant, soil moisture at these depths was not. Changes in surface $\theta$, whether from infiltration of meltwater and/or thawing of frozen surface soils, propagated through the soil profile all the way to $-30 \mathrm{~cm}$ depth, creating very dynamic moisture conditions that may be characteristic of future soil $\theta$ conditions in seasonally snow-covered areas given climate change. These fluctuations in $\theta$ at -15 and $-30 \mathrm{~cm}$ were chiefly responsible for driving $F_{\text {soil }}$ and $F_{\text {soil-snow }}$ rates such that higher $\theta$ led to lower rates of $F_{\text {soil }}$ and $F_{\text {soil-snow. }}$

Our finding that $\theta$ negatively impacts soil $\mathrm{CO}_{2}$ flux differs from previously reported relationships between soil moisture and winter soil respiration dynamics. Both Hirano [2014] and Schindlbacher et al. [2014] cited positive relationships between $\theta$ and winter soil respiration in cool temperate forests, and both suggested that snowmelt flushed labile $C$ into soil, relieving water and substrate limitations and thereby boosting respiration rates. Reports from high alpine and subalpine areas have also demonstrated higher winter soil respiration with increasing $\theta$ prior to the main snowmelt season [Liptzin et al., 2009]. However, moisture can also diminish respiration if water-filled pore spaces reduce oxygen availability and slow $\mathrm{CO}_{2}$ diffusion [Davidson et al., 1998; Moldrup et al., 2000; Aanderud et al., 2013]. This can result across a complex terrain with well-drained and poorly drained soils [Riveros-Iregui et al., 2012] or within a single, topographically diverse meadow [Knowles et al., 2015]. Our study suggests a similar phenomenon within a single soil-to-snow profile in which higher moisture stimulates respiration near the soil surface even as it suppresses respiration at depth within the soil profile. During both of the winters we sampled, $\theta$ levels at -15 and $-30 \mathrm{~cm}$ were 2 to 3 times higher than what we have observed at the same site during the growing season, suggesting that high volumetric water content in these soils during winter does inhibit microbial $\mathrm{CO}_{2}$ efflux. Such high wintertime moisture 
conditions may occur at other sites, but the paucity of winter measurements of soil microclimate extending to $-30 \mathrm{~cm}$ depth limits our ability to draw direct comparisons between our data and those of other studies. The extent to which moisture stimulates or inhibits respiration may arise from a combination of climatic, topographic, and/or edaphic features such as temperature, precipitation, slope, soil texture, bulk density, and organic matter content [Moyano et al., 2012; Riveros-Iregui et al., 2012; Stielstra et al., 2015] that create distinct subnivean environments, both across a horizontal landscape and within a vertical profile.

In addition to exerting a negative control on soil $\mathrm{CO}_{2}$ flux, the dominance of $\theta$ in regulating both $F_{\text {soil }}$ and $F_{\text {soil-snow }}$ is a novel finding in the sense that soil temperature-not moisture-is typically considered a primary driver of both winter and growing season soil respiration in humid temperate forests such as our study site [Mo et al., 2005; Maier et al., 2011; Wang et al., 2013]. In fact, the annual rate of soil C loss both for empirical and Earth system models is typically determined by exponential temperature-respiration functions with moisture playing a secondary role [Davidson et al., 2006a; Todd-Brown et al., 2014]. Consequently, the magnitude of moisture-related changes in the annual ecosystem or global soil $C$ budgets is highly uncertain [Falloon et al., 2011; Moyano et al., 2013], with even greater ambiguity in winter soil moisture and soil respiration dynamics due to a paucity of measurements and data-model integration. The nonlinear, logistic relationship we observed between soil temperature and moisture around $0^{\circ} \mathrm{C}$ suggests an interactive relationship between temperature, $\theta$, and soil respiration that would not be addressed in empirical, process-based, and/or Earth system models [Davidson et al., 1998; Falloon et al., 2011; Moyano et al., 2013].

Snow depth may be an important variable in driving this interactive relationship; it has been long understood to be a key determinant of soil temperature, moisture, and $\mathrm{CO}_{2}$ efflux during winter [Sommerfeld et al., 1993; Brooks et al., 1997; Fahnestock et al., 1998; Groffman et al., 2006; Muhr et al., 2009; Aanderud et al., 2013; Wang et al., 2013]. Indeed, our data show that $F_{\text {snow }}$ was highest when snow was deepest in the middle part of the winter of 2014. This deep snow likely promoted high enough temperatures and liquid water availability at the soil surface to stimulate microbial respiration that was able to quickly diffuse into the overlaying snowpack due to the absence of the very wet conditions that occurred deeper in the profile. However, the snowpack was not always deep but rather frequently decreased in depth and SWE with higher air temperatures. This dynamic snowpack likely created meltwater that infiltrated into the soil throughout the winter, creating equally dynamic and very moist conditions at -15 and $-30 \mathrm{~cm}$ that either suppressed $\mathrm{CO}_{2}$ efflux, slowed diffusion, or both [Orchard and Cook, 1983]. In this way, respiration at the soil surface and through the snowpack may have been promoted even as $\mathrm{CO}_{2}$ production and efflux from deeper in the soil was suppressed. Such complex, bidirectional relationships among environmental drivers and $\mathrm{CO}_{2}$ dynamics are neither represented in empirical, temperature-driven depictions of annual soil respiration [Davidson et al., 2006a] nor are they fully articulated in process-based models of soil C efflux [Blagodatsky and Smith, 2012].

The dynamic interchange we observed among snow depth, soil temperature, and soil moisture across the soil-to-snow profile may depart from previous studies of winter soil respiration due to climatic differences among study sites. Most previous work on winter $\mathrm{CO}_{2}$ flux has occurred in drier and/or colder areas where soils do not exhibit high soil moisture until snowmelt due to deeper and more persistent snowpacks [e.g., Sommerfeld et al., 1996; Brooks et al., 1997; McDowell et al., 2000; Suzuki et al., 2006; Bowling et al., 2009; Liptzin et al., 2009; Seok et al., 2009, 2014; Björkman et al., 2010; Moyes and Bowling, 2013; Hirano, 2014; Schindlbacher et al., 2014; Stielstra et al., 2015]. By contrast, our study site is one where episodic midwinter melt and rain-on-snow events do occur, leading to a very wet soil environment throughout the winter similar to conditions during the main snowmelt period. Thus, our understanding of the relative controls of temperature and moisture on winter $\mathrm{CO}_{2}$ flux may be biased by conceptual models more appropriate for colder and drier areas, where soil microclimate is more stable until spring melt. For example, according to the conceptual representations put forth by Liptzin et al. [2009] and Brooks et al. [2011] illustrating how snow depth determines winter soil microbial activity, our study site should fall within "Zone I," such that shallow, intermittent snow cover drives winter respiration rates, primarily through episodic release of $\mathrm{CO}_{2}$ during free-thaw. However, our site also exhibits characteristics of Zone II (temperature dominated) and Zone III (substrate and moisture dominated). Knowles et al. [2016] likewise suggested that temperature and moisture limitations can affect winter soil respiration in Zone I areas. In the case of Knowles et al. [2016], these were attributed to edaphic properties that impacted soil temperature and water-holding capacity, while our research highlights the role of snowmelt events that drive soil microclimate. Both scenarios suggest that winter soil $\mathrm{CO}_{2}$ loss in 
Zone I areas may be more variable than current models predict. It may be that near-surface soils can experience conditions akin to those in Zones I and II, while soils at depth, which are more insulated from the atmosphere, exhibit characteristics akin to Zones II and III. To our knowledge, we are the first study to examine winter soil respiration across a soil-to-snow profile and one of few studies continuously quantifying winter $\mathrm{CO}_{2}$ fluxes in a cool, humid, temperate forest. It is not clear the extent to which other humid, temperate forests or other soil-to-snow gradients in montane, alpine, or arctic ecosystems might exhibit these characteristics. Yet accurate portrayals of winter soil $\mathrm{C}$ production and loss are essential to modeling the future terrestrial C cycle, particularly given predictions of reduced seasonal snow cover both in temperate areas and globally [Dye, 2002; Déry and Brown, 2007; Lawrence and Slater, 2010; Mudryk et al., 2014].

Higher winter air temperatures, increased winter precipitation, and decreased snow cover are all expected to occur over northern North America, northern Europe, and northern Asia over the 21st century [Christensen et al., 2013]. These climatic trends may increase the frequency of episodic snowmelt and rain events that replenish $\theta$ during the winter months [Kellomäki et al., 2010], creating the dynamic and very moist conditions we observed in our study. Thus, the considerable variation in snowpack and soil microclimate that we documented at our research site is likely to occur over broad areas during the coming century, suggesting that soil moisture may play a greater role in controlling winter soil $\mathrm{C}$ losses than it has historically.

Although our study features a novel and dynamic interplay of snow depth, soil temperature, and soil moisture in influencing winter $\mathrm{CO}_{2}$ flux from soils and the snowpack, we encountered several issues that may have impacted our results. First, we used empirical models of diffusion instead of in situ measurements [Maier and Schack-Kirchner, 2014]. The choice of empirical model can strongly influence calculated $\mathrm{CO}_{2}$ flux rates [Pingintha et al., 2010], particularly in heterogeneous soils with high rock content, such as at our study site [Davidson et al., 2006b]. We used the Moldrup et al. [1997] soil tortuosity model because it produced more realistic estimates of diffusion than other empirical models, and we also applied a correction factor for the coarse rock fraction [e.g., Davidson et al., 2006b]. Nevertheless, we recognize that these measures may have been insufficient to generate accurate estimates of diffusion. While we cannot verify our diffusion estimates with measured values, our average diffusion coefficients for snow $\left(0.08 \mathrm{~cm}^{2} \mathrm{~s}^{-1}\right)$ and soil $\left(0.005 \mathrm{~cm}^{2} \mathrm{~s}^{-1}\right)$ were well within the range of other studies [Solomon and Cerling, 1987; Davidson et al., 2006b]. In addition to potential issues with calculating diffusion, our rates of $F_{\text {soil }}$ may have been overestimated since continuous operation of solid state $\mathrm{CO}_{2}$ sensors can result in soil warming that stimulates microbial activity [Jassal et al., 2005]. Likewise, rates of $F_{\text {snow }}$ may have been underestimated in high wind conditions when advection can pump $\mathrm{CO}_{2}$ out of the snowpack [Seok et al., 2009; Bowling and Massman, 2011]. Unfortunately, the lack of significant correlations between either snow $\mathrm{CO}_{2}$ concentrations or fluxes $\left(F_{\text {snow }}\right)$ and winds measured in a nearby, open pasture meant that we could not determine the impact of advection on our flux estimates. Further, we acknowledge that active gas sampling of $\mathrm{CO}_{2}$ from snow can alter the concentration gradient within the snowpack, thereby underestimating the actual flux [Albert and Shultz, 2002; Seok et al., 2009, 2014; Maier and Schack-Kirchner, 2014]. Sampling each inlet for $10 \mathrm{~min}$ likely exacerbated this problem, as the $11.6 \mathrm{~cm}$ radius of the sphere of gas we sampled would overlap between inlets placed $20 \mathrm{~cm}$ apart. Any of the possible biases in determining $F_{\text {soil }}$ and $F_{\text {snow }}$ may have impacted our calculation of $F_{\text {soil-snow }}$ as we interpolated between $F_{\text {soil }}$ and $F_{\text {soil-snow }}$ to estimate the flux of $\mathrm{CO}_{2}$ from soils to the overlying snowpack. Despite these potential pitfalls, we believe that we have reasonably captured $F_{\text {soill }} F_{\text {soil-snow }}$ and $F_{\text {snow }}$ and their drivers during the winters of 2013 and 2014 at our study site. Our calculations of $F_{\text {soill }}, F_{\text {soil-snow, }}$ and $F_{\text {snow }}$ fell within the range of values reported for previous research on winter soil respiration [Schindlbacher et al., 2007; Seok et al., 2009; Hirano, 2014; Schindlbacher et al., 2014]. Cumulative fluxes of $F_{\text {soil }}$ and the combination of $F_{\text {soil-snow }}$ and $F_{\text {snow }}$ also agreed with other estimates of total seasonal flux [e.g., Contosta et al., 2011; Schindlbacher et al., 2014; Stielstra et al., 2015], suggesting that measuring $\mathrm{CO}_{2}$ at different depths in the soil and the overlying snowpack may produce reliable estimates of winter $\mathrm{C}$ loss.

Future work will address the issues outlined above, including in situ measurements of diffusion, intermittent instead of continuous operation of $\mathrm{CO}_{2}$ sensors, and quantification of wind speeds beneath the forest canopy at $1.5 \mathrm{~m}$ above the forest floor. Additional years of data collection across multiple sites capturing a range of environmental conditions should also elucidate whether the patterns we observed in $F_{\text {soill }}, F_{\text {soil-snow, }}$ and $F_{\text {snow }}$ and their environmental drivers are representative of winter soil $\mathrm{CO}_{2}$ dynamics in humid temperate 


\section{Acknowledgments}

The data for this paper are available at the NH EPSCoR Data Discovery Center (http://ddc.unh.edu/). Partial funding for this research was provided by the New Hampshire Agricultural Experiment Station. This is scientific contribution 2699 , which was supported by the USDA National Institute of Food and Agriculture Hatch Project $\mathrm{NH} 00550$. Additional funding was provided by the UNH ADVANCE Collaborative Scholars Award (NSF 1209189) and the NH EPSCoR Ecosystem and Society Project (NSF-EPS 1101245). We would like to thank B. Godbois, G. Mulukutla, C. Cook and C. Jordan for field and technical assistance. forests. Such data are critical for understanding future winter soil C cycling in seasonally snow-covered ecosystems globally predicted to experience the shorter winters, shallower snowpacks, and rapidly fluctuating soil microclimate typical of our study site in the northeastern U.S.

\section{References}

Aanderud, Z. T., S. E. Jones, D. R. Schoomaster Jr., N. Fierer, and J. T. Lennon (2013), Sensitivity of soil respiration and microbial communities to altered snowfall, Soil Biol. Biochem., 57, 217-227.

Albert, M. R., and E. F. Shultz (2002), Snow and firn properties and air-snow transport processes at Summit, Greenland, Atmos. Environ., 36 , 2789-2797, doi:10.1016/S1352-2310(02)00119-X.

Berryman, E. M., H. R. Barnard, H. R. Adams, M. A. Burns, E. Gallo, and P. D. Brooks (2015), Complex terrain alters temperature and moisture limitations of forest soil respiration across a semiarid to subalpine gradient, J. Geophys. Res. Biogeosci., 120, 707-723, doi:10.1002/ $2014 J G 002802$.

Billings, S. A., D. D. Richter, and J. Yarie (1998), Soil carbon dioxide fluxes and profile concentrations in two boreal forests, Can. J. For. Res., 28, 1773-1783.

Björkman, M. P., E. Morgner, E. J. Cooper, B. Elberling, L. Klemedtsson, and R. G. Björk (2010), Winter carbon dioxide effluxes from Arctic ecosystems: An overview and comparison of methodologies, Global Biogeochem. Cycles, 24, GB3010, doi:10.1029/2009GB003667.

Blagodatsky, S., and P. Smith (2012), Soil physics meets soil biology: Towards a better mechanistic prediction of greenhouse gas emissions from soil, Soil Biol. Biochem., 47, 78-92.

Bowling, D. R., and W. J. Massman (2011), Persistent wind-induced enhancement of diffusive $\mathrm{CO}_{2}$ transport in a mountain forest snowpack J. Geophys. Res., 116, G04006, doi:10.1029/2011JG001722.

Bowling, D. R., W. J. Massman, S. M. Schaeffer, S. P. Burns, R. K. Monson, and M. W. Williams (2009), Biological and physical influences on the carbon isotope content of $\mathrm{CO}_{2}$ in a subalpine forest snowpack, Niwot Ridge, Colorado, Biogeochemistry, 95, 37-59.

Brooks, P. D., S. K. Schmidt, and M. W. Williams (1997), Winter production of $\mathrm{CO}_{2}$ and $\mathrm{N}_{2} \mathrm{O}$ from alpine tundra: Environmental controls and relationship to inter-system C and N fluxes, Oecologia, 110, 403-413.

Brooks, P. D., P. Grogan, P. A. Templer, P. Groffman, M. G. Öquist, and J. Schimel (2011), Carbon and nitrogen cycling in snow-covered environments, Geogr. Compass, 5, 682-699.

Bubier, J., P. Crill, and A. Mosedale (2002), Net ecosystem $\mathrm{CO}_{2}$ exchange measured by autochambers during the snow-covered season at a temperate peatland, Hydrol. Processes, 16, 3667-3682.

Burakowski, E. A., C. P. Wake, B. Braswell, and D. P. Brown (2008), Trends in wintertime climate in the northeastern United States: 1965-2005, J. Geophys. Res., 113, D20114, doi:10.1029/2008JD009870.

Burnham, K. P., and D. R. Anderson (2002), Model Selection and Multimodel Inference, Springer, New York.

Christensen, J. H., et al. (2013), Climate phenomena and their relevance for future regional climate change, in Climate Change 2013: The Physical Science Basis. Contribution of Working Group I to the Fifth Assessment Report of the Intergovernmental Panel on Climate Change, edited by T. F. Stocker et al., Cambridge Univ. Press, Cambridge, U. K., and New York.

Contosta, A. R., S. D. Frey, and A. B. Cooper (2011), Seasonal dynamics of soil respiration and N mineralization in chronically warmed and fertilized soils, Ecosphere, 2, 1-21, doi:10.1890/ES10-00133.1.

Davidson, E. A., E. Belk, and R. D. Boone (1998), Soil water content and temperature as independent or confounded factors controlling soi respiration in a temperate mixed hardwood forest, Global Change Biol., 4, 217-227.

Davidson, E. A., I. A. Janssens, and Y. Luo (2006a), On the variability of respiration in terrestrial ecosystems: Moving beyond $Q_{10}$, Global Change Biol., 12, 154-164.

Davidson, E. A., K. E. Savage, S. E. Trumbore, and W. Borken (2006b), Vertical partitioning of soil $\mathrm{CO}_{2}$ production within a temperate forest soil, Global Change Biol., 12, 944-956.

DeForest, J. L., A. Noormets, S. G. McNulty, G. Sun, G. Tenney, and J. Chen (2006), Phenophases alter the soil respiration temperature relationship in an oak dominated forest, Int. J. Biometeorol., 51, 135-144.

Déry, S. J., and R. D. Brown (2007), Recent Northern Hemisphere snow cover extent trends and implications for the snow-albedo feedback, Geophys. Res. Lett., 34, L22504, doi:10.1029/2007GL031474.

Diamond, H. J., et al. (2013), U.S. Climate Reference Network after one decade of operations: Status and assessment, Bull. Am. Meteorol. Soc., 94, 489-498, doi:10.1175/BAMS-D-12-00170.1.

Duplessis, J. P., and J. H. Masliyah (1991), Flow through isotropic granular porous-media, Transp. Porous Media, 6, $207-221$.

Dye, D. J. (2002), Variability and trends in the annual snow-cover cycle in Northern Hemisphere land areas, 1972-2000, Hydrol. Processes, 16, 3065-3077.

Fahnestock, J. T., M. H. Jones, P. D. Brooks, D. A. Walker, and J. M. Welker (1998), Winter and early spring $\mathrm{CO}_{2}$ efflux from tundra communities of northern Alaska, J. Geophys. Res., 103, 29,023-29,027, doi:10.1029/98JD00805.

Falloon, P., C. D. Jones, M. Ades, and K. Paul (2011), Direct soil moisture controls of future global soil carbon changes: An important source of uncertainty, Global Biogeochem. Cycles, 25, GB3010, doi:10.1029/2010GB003938.

Groffman, P. M., J. P. Hardy, C. T. Driscoll, and T. J. Fahey (2006), Snow depth, soil freezing, and fluxes of carbon dioxide, nitrous oxide and methane in a northern hardwood forest, Global Change Biol., 12, 1748-1760, doi:10.1111/j.1365-2486.2006.01194.x.

Grömping, U. (2006), Relative importance for linear regression in R: The package relaimpo, J. Stat. Software, 17(1), 1-27.

Hayhoe, K. H., et al. (2007), Past and future changes in climate and hydrological indicators in the US Northeast, Clim. Dyn., $28,381-407$.

Hirano, T. (2014), Seasonal and diurnal variations in topsoil and subsoil respiration under snowpack in a temperate deciduous forest, Global Biogeochem. Cycles, 19, GB2011, doi:10.1029/2004GB002259.

Hirano, T., H. Kim, and Y. Tanaka (2003), Long-term half-hourly measurement of soil $\mathrm{CO}_{2}$ concentration and soil respiration in a temperate deciduous forest, J. Geophys. Res., 108(D20), 4631, doi:10.1029/2003JD003766.

lyamada, I., and S. Hasegawa (2005), Gas diffusion coefficient of undisturbed peat soils, Soil Sci.Plant Nutr., 51, 431-435.

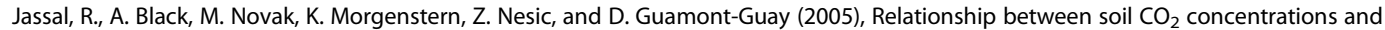
forest-floor $\mathrm{CO}_{2}$ effluxes, Agric. For. Meteorol., 130, 176-192.

Kellomäki, S., M. Maajärvi, H. Strandman, A. Kilpeläinen, and H. Peltola (2010), Model computations on the climate change effects on snow cover, soil moisture and soil frost in the boreal conditions over Finland, Silva Fenn., 44, 213-233.

Knowles, J. F., P. D. Blanken, and M. W. Williams (2015), Soil respiration variability across a soil moisture and vegetation community gradient within a snow-scoured alpine meadow, Biogeochemistry, 125, 185-202, doi:10.1007/s10533-015-0122-3. 
Knowles, J. F., P. D. Blanken, and M. W. Williams (2016), Wet meadow ecosystems contribute the majority of overwinter soil respiration from snow-scoured alpine tundra, J. Geophys. Res. Biogeosci., 121, 1118-1130, doi:10.1002/2015JG003081.

Kulmatiski, A., D. J. Vogt, T. G. Siccama, and K. H. Beard (2003), Detecting nutrient pool changes in rocky forest soils, Soil Sci. Soc. Am. J., 67, $1282-1286$

Lawrence, D. M., and A. G. Slater (2010), The contribution of snow condition trends to future ground climate, Clim. Dyn., 34, 969-981.

Liptzin, D., M. W. Williams, D. Helmig, B. Seok, G. Filippa, K. Chowanski, and J. Hueber (2009), Process-level controls on $\mathrm{CO}_{2}$ fluxes from a seasonally snow-covered subalpine meadow soil, Niwot Ridge, Colorado, Biogeochemistry, 95, 151-166.

Luce, C. H., and D. G. Tarboton (2001), A modified force-restore approach to modeling snow-surface heat fluxes paper presented at the 69th Annual Meeting of the western Snow Conference, 2001

Maier, M., and H. Schack-Kirchner (2014), Using the gradient method to determine soil gas flux: A review, Agric. For. Meteorol., 192-193, 78-95.

Maier, M., H. Schack-Kirchner, E. E. Hildebrand, and D. Schindler (2011), Soil $\mathrm{CO}_{2}$ efflux vs. soil respiration: Implications for flux models, Agric. For. Meteorol., 151, 1723-1730, doi:10.1016/j.agrformet.2011.07.006.

McDowell, N. G., J. D. Marshall, T. D. Hooker, and R. Musselman (2000), Estimating $\mathrm{CO}_{2}$ flux from snowpacks at three sites in the Rocky Mountains, Tree Physiol., 20, 745-753.

Millington, R. J., and J. P. Quirk (1961), Permeability of porous solids, Trans. Faraday Soc., 57, 1200-1207.

Mo, W., M.-S. Lee, M. Uchida, M. Inatomi, N. Saigusa, S. Mariko, and H. Koizumi (2005), Seasonal and annual variations in soil respiration in a cool-temperate deciduous broad-leaved forest in Japan, Agric. For. Meteorol., 134, 81-94.

Moldrup, P., T. Olesen, D. E. Rolston, and T. Yamaguchi (1997), Modeling diffusion and reaction in soils, VII. Predicting gas and ion diffusivity in undisturbed and sieved soils, Soil Sci., 162, 632-640.

Moldrup, P., T. Olesen, J. Gamst, P. Schjønning, T. Yamaguchi, and D. E. Rolston (2000), Predicting the gas diffusion coefficient in repacked soil: Water-induced linear reduction model, Soil Sci. Soc. Am. J., 64, 1588-1594.

Moyano, F. E., et al. (2012), The moisture response of soil heterotrophic respiration, interaction with soil properties, Biogeosciences, 9 , 1173-1182, doi:10.5194/bg-9-1173-2012.

Moyano, F. E., S. Manzoni, and C. Chenu (2013), Responses of soil heterotrophic respiration to moisture availability: An exploration of processes and models, Soil Biol. Biochem., 59, 72-85, doi:10.1016/j.soilbio.2013.01.002.

Moyes, A. B., and D. R. Bowling (2013), Interannual variation in seasonal drivers of soil respiration in a semi-arid Rocky Mountain meadow, Biogeochemistry, 113, 683-697, doi:10.1007/s10533-012-9797-x.

Mudryk, L. R., P. J. Kushner, and C. Derksen (2014), Interpreting observed northern hemisphere snow trends with large ensembles of climate simulations, Clim. Dyn., 43, 345-359.

Muhr, J., W. Borken, and E. Matzner (2009), Effects of soil frost on soil respiration and its radiocarbon signature in a Norway spruce forest soil, Global Change Biol., 15, 782-793, doi:10.1111/j.1365-2486.2008.01695.x.

New Hampshire State Climate Office (2014), Climatic normals (1981-2010) for selected New Hampshire cities and towns. [Available at http:// www.unh.edu/stateclimatologist/NHnormals.html.]

Orchard, V. A., and F. J. Cook (1983), Relationship between soil respiration and soil moisture, Soil Biol. Biochem., 15, 447-453.

Panikov, N. S., P. W. Flanagan, W. C. Oechel, M. A. Mastepanov, and T. R. Christensen (2006), Microbial activity in soils frozen to below $-39^{\circ} \mathrm{C}$ Soil Biol. Biochem., 38, 785-794, doi:10.1016/j.soilbio.2005.07.004.

Pingintha, N., M. Y. Leclerc, J. P. Beasley Jr., G. Zhang, and C. Senthong (2010), Assessment of the soil $\mathrm{CO}_{2}$ gradient method for soil $\mathrm{CO}_{2}$ efflux measurements, comparison of six models in the calculation of the relative gas diffusion coefficient, Tellus, Ser. B, 62, 47-58.

Pinhiero, J., D. Bates, S. DebRoy, D. Sarkar, and the R Core team (2009), nlme, linear and nonlinear mixed effects models, R package version 3.1-93.

R Core Team (2015), R: A Language and Environment for Statistical Computing, R Foundation for Statistical Computing, Vienna, Austria. [Available at https://www.R-project.org/.]

Riveros-Iregui, D. A., B. L. McGlynn, H. E. Epstein, and D. L. Welsch (2008), Interpretation and evaluation of combined measurement techniques for soil $\mathrm{CO}_{2}$ efflux: Discrete surface chambers and continuous soil $\mathrm{CO}_{2}$ concentration probes, J. Geophys. Res., 113, G04027, doi:10.1029/2008JG000811.

Riveros-Iregui, D. A., B. L. McGlynn, R. E. Emanuel, and H. E. Epstein (2012), Complex terrain leads to bidirectional responses of soil respiration to inter-annual water availability, Global Change Biol., 18, 749-756, doi:10.1111/j.1365-2486.2011.02556.x.

Savage, K. E., and E. A. Davidson (2001), Interannual variation in soil respiration in two New England Forests, Global Biogeochem. Cycles, 15, 337-350, doi:10.1029/1999GB001248.

Schindlbacher, A., S. Zechmeister-Boltenstern, G. Glatzel, and R. Jandl (2007), Winter soil respiration from an Austrian mountain forest, Agric For. Meteorol., 146, 205-215.

Schindlbacher, A., R. Jandl, and S. Schindlbacher (2014), Natural variations in snow cover do not affect the annual soil $\mathrm{CO}_{2}$ efflux from a mid-elevation temperate forest, Global Change Biol., 20, 622-632, doi:10.1111/gcb.12367.

Seok, B., D. Helmig, M. W. Williams, D. Liptzin, K. Chowanski, and J. Hueber (2009), An automated system for continuous measurements of trace gas fluxes through snow: An evaluation of the gas diffusion method at a subalpine forest site, Niwot Ridge, Colorado, Biogeochemistry, 95, 95-113.

Seok, B., D. Helmig, D. Liptzin, M. W. Williams, and C. S. Vogel (2014), Snowpack-atmosphere gas exchanges of carbon dioxide, ozone, and nitrogen oxides at a hardwood forest site in northern Michigan, Elementa, 3, 000040, doi:10.12952/journal.elementa.000040.

Solomon, D. K., and T. E. Cerling (1987), The annual carbon dioxide cycle in a montane soil: Observations, modeling, and implications for weathering, Water Resour. Res., 23, 2257-2265, doi:10.1029/WR023i012p02257.

Sommerfeld, R. A., A. R. Mosier, and R. C. Musselman (1993), $\mathrm{CO}_{2}, \mathrm{CH}_{4}$ and $\mathrm{N}_{2} \mathrm{O}$ flux through a Wyoming snowpack and implications for global budgets, Nature, 361, 140-142.

Sommerfeld, R. A., W. J. Massman, and R. C. Musselman (1996), Diffusional flux of CO: Through snow: Spatial and temporal variability among alpine-subalpine sites, Global Biogeochem. Cycles, 10, 473-482, doi:10.1029/96GB01610.

Spaans, E. J. A., and J. M. Baker (1996), The soil freezing characteristic: Its measurement and similarity to the soil moisture characteristic, Soil Sci. Soc. Am. J., 60, 13-19.

Stielstra, C. M., K. A. Lohse, J. Chorover, J. C. Mclntosh, G. A. Barron-Gafford, J. N. Perdrial, M. Litvak, H. R. Barnard, and P. D. Brooks (2015), Climatic and landscape influences on soil moisture are primary determinants of soil carbon fluxes in seasonally snow-covered forest ecosystems, Biogeochemistry, 123, 447-465, doi:10.1007/s10533-015-0078-3.

Suzuki, S., S. Ishizuka, K. Kitamura, K. Yamanoi, and Y. Nakai (2006), Continuous estimation of winter carbon dioxide efflux from the snow surface in a deciduous broadleaf forest, J. Geophys. Res., 111, D17101, doi:10.1029/2005JD006595. 
Tang, J., D. D. Baldocchi, Y. Qi, and L. Xu (2003), Assessing soil $\mathrm{CO}_{2}$ efflux using continuous measurements of $\mathrm{CO}_{2}$ profiles in soils with small solid state sensors, Agric. For. Meteorol., 118, 207-220.

Tian, Z., J. Heitman, R. Horton, and T. Ren (2015), Determining soil ice contents during freezing and thawing with thermos-time domain reflectrometry, Vadose Zone J., doi:10.2136/vzj2014.12.179.

Todd-Brown, K. E. O., et al. (2014), Changes in soil organic carbon storage predicted by Earth system models during the 21st century, Biogeosciences, 11, 2341-2356.

Vargas, R., et al. (2010), Looking deeper into the soil: Biophysical controls and seasonal lags of soil $\mathrm{CO}_{2}$ production and efflux, Ecol. Appl., 20, 1569-1582.

Wang, C., Y. Han, J. Chen, X. Wang, Q. Zhang, and B. Bond-Lamberty (2013), Seasonality of soil $\mathrm{CO}_{2}$ efflux in a temperate forest: Biophysical effects of snowpack and spring freeze-thaw cycles, Agric. For. Meteorol., 177, 83-92.

Zhang, T., R. G. Barry, and R. L. Armstrong (2004), Application of satellite remote sensing techniques to frozen ground studies, Polar Geogr. 28, 163-196.

Zuur, A. F., E. N. lena, N. Walker, A. A. Saveliev, and G. M. Smith (2009), Mixed Effects Models and Extensions in Ecology with R, Springer, New York.

Zuur, A. F., E. N. leno, and C. S. Elphick (2010), A protocol for data exploration to avoid common statistical problems, Methods Ecol. Evol., 1, $3-14$ 